\title{
WHEN CHARLES DICKENS ENTERS THE HOUSE OF FICTION: PETER CAREY'S JACK MAGGS AND JOSEPH O'CONNOR'S STAR OF THE SEA ${ }^{1}$
}

\author{
Armelle Parey ${ }^{2}$
}

\begin{abstract}
Charles Dickens is probably THE Victorian novelist posterity remembers best, or at least the most, to the extent that he also occasionally appears as a character of fiction. Part of his private life is thus rewritten in Peter Carey's Jack Maggs (1997) which also dwells on his activity as a writer, pretending to account for the circumstances of the writing of Great Expectations. Dickens has also appeared in Joseph O'Connor's Star of the Sea (2002), where circumstances for his writing are emphasized too. This paper is thus a modest attempt at assessing these fictional representations of Charles Dickens in today's novels.

Key-words: Charles Dickens, Peter Carey, Joseph O’Connor, rewriting, Postmodern novels, self-reflexivity.

Resumen: Charles Dickens probablemente es EL novelista victoriano que la posteridad mejor recuerda, o al menos, al que más recuerda, hasta el punto de que ocasionalmente aparece como un personaje de ficción. Así, un parte de su vida privada está reescrita en la novela Jack Maggs de Peter Carey (1997) que también se concentra en su actividad como escritor, fingiendo explicar las circunstancias de la novela Great Expectations. Además Dickens tuvo un papel en Star of the Sea de Joseph O'Connor (2002), donde están enfatizadas las circunstancias por su escritura también. Así, este artículo intenta evaluar estas representaciones ficticias de Charles Dickens en las novelas de hoy.

Palabras clave: Charles Dickens, Peter Carey, Joseph O'Connor, reescritura, novelas postmodernas, autoreflexión.
\end{abstract}

Charles Dickens is probably THE Victorian novelist posterity remembers best, or at least the most. Even if "his work was widely underrated, or even dismissed, by highbrow critics until the 1950s" (Sanders 2003: 176), it seems that Dickens's popularity among the public never really faltered. In the words of Andrew Sanders:

the immediate rapport that Dickens the writer had with his original audience seems to have been passed on from generation to generation. That special rapport is still effective at the beginning of the twenty-first century. No other English novelist carries with him quite so much popular baggage. (2003: 177)

\footnotetext{
Date of reception: March 2008.

Date of acceptance and final version: July 2008.

2 Lecturer, UFR des Langues Vivantes Etrangères, Universidad de Caen Basse Normandie; $\square$ armelle. parey@unicaen.fr.
} 
His novels are still adapted to the screen (the latest one to date being Roman Polanski's Oliver Twist in 2005), not to mention the regular flow of BBC adaptations of his novels for television.

A consequence of this lasting popularity is that his work has become the background to many neo-Victorian novels of the 1980s and 1990s. As George Letissier puts it, "from many regards, Dickens is the emblematic figure of Victorian fiction, if not of the Victorian era. As one might expect, many Post-Victorian novels write after, or against him" (Letissier 2004: 113). Georges Letissier refers here to the novelist's work but we propose to take the personal pronoun first literally. Indeed, apart from his impact as a novelist, the man himself is undeniably a figure of interest: Peter Ackroyd's extensive 1990 biography was thus re-edited as an abridged version in 1994, a three-part TV series was presented by Peter Ackroyd on BBC 2 in 2002, Peter Ackroyd also wrote a play staging Simon Callow in The Mystery of Charles Dickens, presented at the Albery Theatre in London in 2000.

More strangely perhaps, Dickens has also become a character IN fiction. Some novels feature a character named Dickens or identifiable as such who is described physically and psychologically in a fictional context. The emphasis is laid on his private life and/or his work as a novelist. As early as 1928, a novel by C.E. Bechhoffer-Roberts entitled This Side Idolatry, a Novel Based on the Life of Charles Dickens focused on the novelist from his birth to his separation with his wife and encounter with actress Ellen Ternan, the rest of his life being told in a couple of paragraphs acting as an epilogue. It "offered an unflattering picture of Dickens as a vain man and a singularly inconsiderate husband" (Sanders 2003: 179). The thesis of this novel is basically that Dickens was anything but the benevolent Victorian paterfamilias one usually tends to imagine. Finally hinting at the falsification of facts and the rewriting of history, it explains how the traditional view emerged. ${ }^{3}$ Closer to us, Peter Ackroyd made him appear in English Music (1992), in a chapter in which the young hero, Timothy Harcombe, meets most of the cast of Great Expectations -some of them in a rebellious mood-including their author under various guises.

Considering Dickens's fame, it is only natural that rewritings of the novelist's work should have stretched beyond the confines of Britain. Dickens is indeed also a landmark for post-colonial writers, one way or another, among whom he elicits mixed reactions: "Postcolonial responses to Dickens are [...] especially complex, since he is seen as occupying a central role in the canon and as an outsider who could be a trenchant critic of the dominant social codes of his day" (2001: 102). I have chosen to focus on representations of Dickens in the work of two writers whose texts can be considered as post-colonial, that is "Anglophone writing from societies that have experienced some form of colonialism in recent centuries" (Thieme 2001: 6), two writers who have dealt with the Victorian ancestor as a persona in the world of fiction. Despite the change in names, Charles Dickens is easily recognizable as the novelist in Peter Carey's Jack Maggs. In this novel published in 1997 Peter Carey partly rewrites Great Expectations from the point of view of the Australian convict and in so doing, dwells on the conditions of production of a landmark text. Dickens

\footnotetext{
The very last lines of the novel do not allow for any ambiguity as the author's position / vision : "Forster, with the aid of Georgina, fulfilled his promise to write Charles' biography. Therein he established the tradition that Charles, the Inimitable Boz, had ever shown himself in his life as in his work the uncompromising foe of cant, hypocrisy and humbug. Kate still kept her silence” (Bechhoffer-Roberts 1928: 349).
} 
also makes a minor but striking appearance as a character in Joseph O'Connor's Star of the Sea (2002), a novel that centres on various characters embarked on a famine ship. In this historiographic metafiction which deals most self-consciously with events at the time of the Irish potato blight, a couple of characters (American journalist Grantley Dixon and Pius Mulvey, Irish thief and murderer) mention a few encounters with Dickens in London.

In both cases the portrait is quite stunning and remarkable for the light it sheds on the great novelist. This paper is thus a modest attempt at assessing these fictional representations of Charles Dickens in today's novels. In other words, how does the Victorian novelist fare in his transfer from life to fiction? What changes does he undergo and why? Indeed, there is necessarily a discrepancy between the past which did exist and its representation. Besides, this representation, which follows the same rules as any narrative, including fiction, is always ideological. So, what do contemporary novelists choose to dwell on and why? Our analysis of the Dickens character in each novel will first focus on the modifications made by the authors on the writer as we know him through non-fictional texts. As Dickens's person is seen as indissociable from his work, representing him is the occasion to comment on the creative process, to offer a new perspective on his way of working. All this finally amounts to an attempt to re-evaluate his legacy, in other words to challenge his portrait of Victorian Britain, both in its form and in its ideological discourse.

Neither of these recent contemporary novels focus on Dickens per se. It is particularly significant in Peter Carey's case, who chooses to throw the light on a secondary character whom he regards as slighted by the Victorian novelist. As the title suggests, Peter Carey's Jack Maggs focuses on the story of Magwitch, explaining why and how he became the convict sent to Australia in Great Expectations. The story starts when the convict, having served his time in Australia and become rich there, comes back to England in hiding to enjoy the company of the boy whose life he has financed. Carey explained in various interviews that he thought the original treatment of the convict was unfair. ${ }^{4}$ His novel deliberately stresses this re-arranging of facts by the author: Jack Maggs includes a novelist character, named Tobias Oates, but, as we shall see, obviously based on Dickens. The novel tells of the battle of power and will between character and writer, how life is transformed into fiction.

Peter Carey draws on well-known features of Dickens's biography in order to make him readily recognizable. Like the Victorian novelist, Oates had a poor and miserable childhood which sparks his interest in social matters: "For Tobias had been a poor child too and was fiercely protective of abused children, famously earnest in defence of the child victims of mill and factory owners" (Carey 1998: 143). In Jack Maggs as in Star of the $\mathrm{Sea}$, the novelist is at the start of his career and enjoys the success and acclaim brought by a comic novel, as was the case for Dickens in 1836 with The Pickwick Papers. In Carey's novel, the young novelist is an occasional journalist and a good mimic. He is married and the portrait of his wife, Mary Oates, depicted as a boring faithful woman is close to that usually made of Dickens's wife, Catherine Hogarth.

Borrowings from Charles Dickens's biography are numerous but they are also sometimes the object of a highly significant distortion. Such is the case of Carey's transposition of Dickens's interest in mesmerism. Dickens actually got involved with a Madame de la

See, for instance, Peter Carey's interview with Ramona Koval (Carey 1997: 667). 
Rue in Genoa. This seems the basis for Oates's treatment of Maggs, as like the ex-convict, she "suffered from a pronounced and disagreeable nervous "tic" or spasm on her face" (1999: 473). He attempted to cure her through mesmerism and in the course of their séances encountered "a phantom who appeared in her dreams and would not let her rest" (Ackroyd 1999: 473) . In Carey's rewriting of this episode, it is the novelist character who plants the "phantom" in the brain of his patient and thus creates the need for his mesmerizing skills. Besides while Ackroyd underlines that Dickens's interest in the experiment is supported by the Lady's husband who read the notes taken during the sessions, Carey portrays deceit and theft. Maggs rightly feels "burgled, plundered" (Carey 1998: 36) after their first encounter in the course of which Oates mesmerized him: when the writer discovers Maggs's secret, he decides to use this unique access to the Criminal mind to document his fiction. ${ }^{5}$

Another major transformation revolves around Dickens's well-known attachment to his wife's younger sister, Mary Hogarth, who lived in Doughty Street with the newly-married couple for a little while before she died suddenly in Dickens's arms. Dickens was devastated to the point that the publication of the Pickwick Papers and Oliver Twist in monthly installments was brought to a halt. It is a well-known fact that "He wore one of her rings for the rest of his life, kept a lock of her hair and her clothes, and said it was impossible to exaggerate her influence on him" (Lodge 2003: 129). Mary is also said to be the possible origin for Dickens's young innocent and pure heroines. Peter Carey transposes the family arrangements in Jack Maggs but offers an altogether different view of the relationship, the reason for her death and for the novelist's subsequent passionate grief. The friendship is indeed turned into a fateful affair as Lizzie Warriner dies (on the same date as Mary Hogarth, i.e. on May $7^{\text {th }} 1837$ ) from taking pills supposed to help them abort Tobias's child. If this revision of the famous friendship is typical of the late 20th-century injection of sexuality in supposedly repressed Victorian characters, it is also a good example of the postmodern rewriting game that challenges the orthodox historical account. The immediate effect of the revision at stake here is that the novelist's unfaithfulness accentuates the portrait of Dickens/Oates as a liar.

Duplicity is also a feature of Dickens when pictured by Joseph O'Connor. In Star of the Sea, Dickens makes a couple of short appearances under his own name. He is only a minor character with no influence on the plot and who occupies merely a few pages. The brevity of his appearance makes the portrait of the novelist all the more striking. It is definitely a negative portrait. He is first seen parading through the eyes of Grantley Dixon, an unlucky would-be novelist: "he had seen that idiot Dickens strolling along Oxford Street doffing his topper like a victorious general among the plebeians." (O'Connor 2003: 122). Later on in the novel, an analepsis portrays him a few years before. When Pius Mulvey meets him in London's seedier quarters, he is "an alarmingly bearded gentleman in tails and a topper [...] creeping the midnight alleyways like a burglar" (2003: 189). Charles Dickens did not wear a beard at the time and the appendage indicates disguise and deceit. Besides, the adverb "alarmingly" suggests that the trick is overdone and does not take in Mulvey, himself a consummate liar. The verb "creeping" suggests cheating and the comparison to

He also devises false records of the sessions not to lose Maggs's trust. 
a thief echoes the one made in Jack Maggs, with the idea that the novelist dispossesses people of their stories.

When Dickens enters fiction, it is first and foremost in relation to his art. In fact, representing the man is always the occasion to pass judgments on the novelist's skills and creative powers. But appreciation varies a lot from one text to the other.

In his extensive biography, Peter Ackroyd celebrates the writer's powers of imagination even though it is a well-known fact that Dickens researched his novels and used his everyday experience and encounters in fiction. While the biographer acknowledges "threats of many libel writs from various real Yorkshire schoolmasters" (Ackroyd 1999: 269) after the publication of Nicholas Nickleby, he also asserts that the real never entered fiction unmediated by Dickens's art and imagination:

there is no doubt that on many occasions Dickens used certain salient characteristics of the people whom he met or knew, but there are very few instances when he simply transcribed what he had seen and heard onto the page. The novelist's art is not of that kind: Dickens perceived a striking characteristic, or mood, or piece of behaviour, and then in his imagination proceeded to elaborate upon it until the "character" bears only a passing ressemblance to the real person. (Ackroyd 1999: 126)

At the same time, the biographer insists on the accuracy of Dickens's representation of people. Ackroyd opens his biography on the novelist's death and on the large surge of sorrow it generated, to be witnessed in the crowds of people who passed by his open grave in procession for two days. Ackroyd comments:

Even to the labouring men and women there was in his death a grievous sense of loss; they felt that he had in large measure understood them and that, in his death, they had also lost something of themselves. [...] can we not say that Dickens captured the soul of the English people, as much in its brooding melancholy as in its broad humour, in its poetry as well as in its fearlessness, in its capacity for outrage and pity as much as in its tendency towards irony and diffidence. (1999: xiv)

This ability that Dickens would have had to understand the humble people, sympathize with them and be their mouthpiece by means of a perfect blend of imagination and observation is exactly what is challenged in Carey's and O'Connor's fictional representations of Dickens.

It is quite enlightening to compare the various ways in which Charles Dickens's relationship with people and characters is represented. In Chapter 4 of Peter Ackroyd's English Music, the novelist projects himself in his characters, he inhabits them, he fills them in with his own self, he inflates life in them as he actually IS Pip and Magwitch. They are his "intradiegetic doubles" (Letissier 2004: 119). The movement is exactly reversed in Carey's and O'Connor's novels, in which the vampire-like novelist sucks in people's stories to feed his fiction. In both novels, the writer is presented as a thief who steals people's stories (even if he sometimes pays to hear them).

Maggs actually calls him "a thief [...] A damned little thief” (Carey 1998: 305) when he realizes that Oates has used his memories to write a novel. More globally, like Dickens 
and probably many other novelists, Tobias Oates uses his own feelings and adventures in everyday life to write his fiction. The end of his novel on Maggs is thus said to be partly suggested by a fire he witnessed and reported in Brighton. This foregrounds the intertwining of private life and feelings with public writing, which is repeatedly suggested through the novel. Events are reworked, rewritten to suit the novelist's purpose. ${ }^{6}$

In Star of the Sea, Joseph O'Connor goes even further. The well-known fact that Dickens was "stimulated by the seamier side of London" (Sanders 2003: 5) takes on a different dimension with an episode suggesting that this is where he copied out the plot for one of his early novels. Dickens approaches Pius Mulvey, then calling himself Frederick Hall, in Limehouse, Whitechapel after hearing him sing a song:

Charlie or Chaz or Charles or Dickens was a writer of stories in literary magazines. He had a great curiosity for the culture of the working man, he said, for the songs and sayings of the labouring classes of London. Anything authentic interested him greatly and he had found Mulvey's song fantastically interesting. Was it terribly old, he wanted to know? How had Mulvey come to learn it? (O'Connor 2003: 190)

The sentences supposedly reporting his speech sound a little out of place, inauthentic in their style: one notes the alliterations in "l" and " $\mathrm{s}$ " in "the songs and sayings of the labouring classes of London", the naive or forceful exaggeration in "great", "greatly", "fantastically" and "terribly". The reader knows that the song is originally an Irish ballad written by Mulvey himself and that he has just "stitched at the text for a couple of nights, affixing ribbons of street names and crests of London slang; unpicking anything too disquieting or too noticeably Irish" (2003: 188) to adapt it to the East End public. The fact that Dickens is fooled says as much in favour of Mulvey's skills as against Dickens's perspicacity and knowledge of the "authentic". Having secured food and drink, "Mulvey spoke to him about the song" (2003: 190). And the story which unfolds in the following paragraph is recognizable as Oliver Twist's:

He had learned it from an aged pickpocket who lived in Holborn, he lied, a Jew who ran a school for young thieves and runaways. It was indeed very old and extremely authentic. Charlie was fascinated; he kept writing down Mulvey's answers, and the faster he wrote them, the faster flowed the lies. Mulvey's ability to lie amazed even himself. Before long he almost believed he was telling the truth, so vivid was the picture of the chuckling, sagacious Israelite, his artful little disciples and the voluble tarts who befriended them. When he ran out of inspiration he started stirring in details from Connemara ballads: the maiden betrayed by the false-hearted aristocrat, the girl of easy virtue murdered by her lover, the poor little waif sent into the workhouse. (O'Connor 2003: 190)

And if confirmation was needed, the name of Fagan is actually given, revengefully chosen by Mulvey. The name, only one letter away from the one used in Oliver Twist, suggests that the novelist has made hardly any changes to Mulvey's tale.

\footnotetext{
6 A point also made in Claire Tomalin's remarkable biography of Charles Dickens's young mistress in The Invisible Woman: "He believed strongly in his own ability to wrench the world into the shape he wanted, the stage manager of real events and lives as well as imaginary ones" (1991: 150).
} 
In common with the portrait depicted by Peter Carey is the reliance on stories provided for others. The situation is the same in providing the source for a famous novel. In both cases, Dickens's famous powers of imagination and observation seem to be seriously diminished. What is portrayed in Star of the Sea is a greedy character thirstily swallowing Mulvey's lies. The Dickens depicted here does not master the situation but is fooled by Mulvey who stands his ground: "Charlie was trying to scalp him, but that was fine. Charlie was being thoroughly scalped himself. The song was an act of mutual robbery" (O'Connor 2003: 190). In Star of the Sea as in Jack Maggs, Dickens is portrayed as trying to take advantage of the poor whose champion he is supposed to be.

Carey and O'Connor challenge Dickens's powers of imagination by showing how he thrived on other people's stories, how he has used, oppressed and robbed the powerless of their voices. He has used them to find himself a place centre stage and once there, has shaped our vision of them in his novels.

By turning the author of a canonical text into a character, Carey invites the reader to witness the creative process. Both Jack Maggs and Star of the Sea take us behind the scenes: they tell us the "making of" of well-known stories to show that the creative process does not take place ex nihilo but is socially and psychologically anchored in a context. For instance, when Tobias burns out the bloody sheets in which Mary has died: "It was Jack Maggs who had done this, and in his grief Tobias began to heap all his blame upon him. It was now, on the seventh of May, in the darkest night of his life, that Jack Maggs began to take the form the world would later know" (Carey 1998: 355). Because he holds Maggs responsible for all his misery, Tobias sees him as a dark threatening monster and will portray him as such. ${ }^{7}$ In including a novelist character and telling his relationship with the convict, Jack Maggs accounts for the way Maggs was fictionalized, how facts came to be distorted, how the convict came to have "his famously 'abhorent' face" (1998: 355). Narrating the genesis of a canonical text means restoring the oppressed their voices or at least giving them their due. These novels tell us tales that summon a revision of our perception of the canon and their authors.

Carey seems intent on our getting the facts right. He stresses the discrepancy between events and their narration, the man and the character in order to correct the poor and inexact portrait made of the "Australian" convict in Great Expectations. The character has completely taken over and the real man is forgotten but for Carey's narrative. In making the reader privy to the fictionalising process undergone by the convict, Carey generally states that writing is ideological and equals power, empowerment and possible entrapment. Through Oates/Dickens, Carey mounts a direct challenge to the idea of observation of real life leading to bare representation, the belief in the novel as objective mirror. Of course, these remarks apply to Carey's own representation of the Victorian novelist. This very selfreflexivity defeats any fixed and final assertion about one or the other.

In Star of the Sea, the reader seems to be invited to side with devious Mulvey for once and laugh at Dickens being done in by the lies the Irish thief sells him. According to the novel, one of the most famous texts in English literature is actually the work of an unknown

\footnotetext{
The situation is very different in Peter Ackroyd's English Music, where Dickens inhabits young Pip as much as Magwitch, which implies sympathy and understanding for both.
} 
and forgotten Irish man. The effect is to challenge Dickens's reputation as the novelist of his century, the writer who best captured his age, in an act of resistance to the dominant cultural perspective. Yet, we know that Dickens has the last word as he is the one who becomes rich and famous with the story whereas Mulvey dies murdered in a slum: there is a limit to what revision can do.

Besides, there is a dimension in the novel that counter-balances the portrayal of the novelist as feeding off his writing with other people's lives. The reader is repeatedly told that facts do not matter as much as the way they are told, something that amoral and opportunistic Mulvey bears in mind when composing ballads, "It didn't really matter. Nobody would ever know the facts anyway [...]. The facts did not matter: that was the secret. He wrote and scratched out; rewrote, refined" (O'Connor 2003: 102). This is the lesson that Grantley Dixon, a journalist and would-be novelist has to learn. He originally resents Dickens's success, a success he deems absolutely unjustified as he is aware his novels are not true to life. Hence the young Dixon's bitter description of Dickens on Oxford Street: "People were rushing to him and shaking his hand, as though he was a hero instead of a charlatan [...]. God, it was dismal how they lapped it up. Please, sir. We want some more" (2003: 122). It is only at the end of his life (and at the end of his book) that Dixon comes to state that "everything is in the way the material is composed" $(2003: 394,397)$. O'Connor's novel thus eventually celebrates the art of the story-teller, asserts his supremacy over facts and simultaneously challenges its own account.

The use of writer figures confers a self-reflexive dimension to these postmodern novels that question their own representations of the past and of its characters. Mulvey's comment at the end of his encounter with Dickens conveys irony and criticism: "There was a living to be made from manufacturing the authentic" (2003: 190). It literally applies to Mulvey of course, as he gets a good dinner and a few pints of beer thanks to his story. However, the oxymoron "manufacturing the authentic" also sarcastically refers to the work of the realist novelist. Yet, Terry Eagleton aptly notes "a Dickensian spaciousness" (Eagleton 2003: 26) in Star of the Sea and Sylvie Mikowski underlines the fact that Mulvey himself has something of a Dickens character (Mikowski 2007: 235). In fact Star of the Sea displays the blend of homage and challenge often to be found in the self-conscious rewritings of the past that historiographic metafictions are.

Charles Dickens embodies the dominant cultural code: his vision of Victorian Britain has shaped ours and still dominates it. Because of his emblematic place in the canon, the young Dickens who seems to have embodied his age so well is the ideal figure for postcolonial writers to vent their anger at. ${ }^{8}$ Both novels thus attempt demythologising, challenge the popular view of Dickens and his place in the canon by making a rather unflattering portrait of the writer as some kind of thief or vampire who sucks up people's stories to write his own novels. Displaying postmodern ambiguity, these novels are self-reflexive while engaging with the English traditional view on Victorian times. These novels" "revision" of Dickens is symptomatic of their iconoclastic presentation of nineteenth-century Britain. The historical and ideological dimension underlying Carey's and O'Connor's writing is made

\footnotetext{
8 As opposed to the older Dickens who, in his late fiction, was darker and farther from the values of the reading public.
} 
obvious by a quick comparison with the deferential way Dickens is treated in a French novel published in 2004. Monsieur Dick by Jean-Pierre Ohl pays unmitigated tribute to the Victorian novelist: his text is pure homage and displays no retaliation; no degradation because there is no contention.

\section{REFERENCES}

Ackroyd, P. 1993. English Music. London: Penguin Books.

1999. Dickens. London: Vintage.

BechHofer-Roberts, C.E. ("Ephesian"). 1928. This Side Idolatry, a Novel Based on the Life of Dickens. Indianapolis: The Bobbs-Merrill Company.

CAREY, P. 1997. "The Unexamined Life". Interview with Ramona Koval, Meanjin 56:3-4: 667-682. . 1998. Jack Maggs. New York: Vintage books.

Eagleton, T. 2003. "Another Country". Rev. of Star of the Sea by Joseph O'Connor. The Guardian 25 January: 26.

Letissier, G. 2004. "Dickens and Post-Victorian Fiction". Refracting the Canon in Contemporary British Literature and Film. Ed. S. OnEGA and C. GuTLEBEN Postmodern Studies 35, Amsterdam: Rodopi. 111-128.

Lodge, D. 2003. "Dickens Our Contemporary". Consciousness and the Novel. Ed. D. LodGe. London: Penguin Books. 114-134.

Mikowski, S. 2007. "Star of the Sea de Joseph O'Connor. Quand la fiction nous mène en bateau". Irlande, écritures et réécritures de la famine. Ed. B. CARDIN and C. Fierobe. Caen: Presses Universitaires de Caen. 231-246.

O’Connor, J. 2003. Star of the Sea. London: Vintage.

OHL, J.P. 2004. Monsieur Dick ou Le dixième livre. Paris: Gallimard.

SANDERs, A. 2003. Charles Dickens. Oxford's World Classics. Oxford: OUP.

Thieme, J. 2001. Postcolonial Con-Texts, Writing Back to the Canon. London: Continuum.

Tomalin, C. 1991. The Invisible Woman, The Story of Nelly Ternan and Charles Dickens. London: Penguin Books. 